\title{
The Future of Health in Sub-Saharan Africa: Is There a Path to Longer and Healthier Lives for All?
}

\author{
Richard G. Wamai and Hugh C. Shirley
}

“This will be Africa's century," so declared a Financial Times article of 30 January 2020 (Jackson 2020). This perspective is a departure over the last decade from representation of a "hopeless continent" in the 13 March 2000 issue of The Economist. The 'Africa optimism' is pegged on population and economic trajectories of a continent that is simultaneously old and young. It is the origin of modern humans (López et al. 2016; Wells 2002) but its countries have been independent from colonial rule for just a few tremendously volatile decades (Meredith 2011). Comprising diverse cultural populations with unique opportunities to study diseases impacting on humankind (Braun and Hammonds 2008; Tishkoff and Williams 2002), Africa's long and short history presents a conundrum in understanding the health of the continent. The history of disease and future of health in Africa is shaped profoundly, not only by its environment and socio-cultural demographics, but also by its contact with the outside world.

Many diseases, including cholera, tuberculosis and syphilis, were introduced to Africa by Europeans and other foreign colonists and merchants (Brynildsrud et al. 2018; Kiple 1993; Patterson 1993; Weill et al. 2017). Globalization has further dispersed populations and diseases such as HIV/AIDS, yellow fever, and trypanosomiasis intra- and intercontinentally (Fetter 1993; Kagaayi and Serwadda 2016; Latham 1993; Lyons 1992; Timberg and Halperin 2012; Worobey et al. 2008). Before the onset of colonialism, indicators of well-being, such as height and nutrition, were better in Africa than in most of the world. For example, population height - which is linked to nutrition and longevity - was greater among Africans on average than nearly all other populations, including those of western Europe during the 1870 os and increased only marginally relative to other regions until the mid-twentieth century, thereafter decreasing or remaining stagnant (Baten and Blum 2014; NCD-RisC 2016).

Post-independence, Africa has lagged behind other world regions in all major health outcomes despite tremendous national and international efforts over the last six decades (Easterly 2006; GBD Collaborators 2018; World Bank $2007,2008)$. Furthermore, after a decade of notable progress during the 1960 s

(C) RICHARD G. WAMAI AND HUGH C. SHIRLEY, 2022 | DOI:10.1163/9789004471641_008

This is an open access chapter distributed under the terms of the CC BY-NC 4.0 License. 
to early 1970s, key health indicators, notably longevity, in sub-Saharan Africa (SSA) deteriorated for the rest of the twentieth century (Jamison et al. 2006; Mwabu 1998; Zijdeman and de Silva 2014) only to begin improving in the last decade (World Bank 2011). Still, ssa had the smallest increase in life expectancy since 1950 at just over forty years and remained the lowest at 63.9 years in 2017 (GBD Collaborators 2018). Thus, the probability of death between birth and age five $\left(\mathrm{O}^{-5}\right)$ and during the productive working years $\left(15^{-65}\right)$ remains greatest in SSA, which additionally carries the greatest burden for maternal and child mortality, as well as nutritional and the numerous vaccine-preventable communicable diseases (GBD Collaborators 2018).

Currently home to one in eight people in the world, ssA will carry one in three by the end of the century (UNDESA 2019a). The health of the global population will not improve in this century without improvements to health in Africa. What are the probable future scenarios of health in Africa? Disease ecologies in SSA were changing long before the prehistoric out-of-Africa migration (López et al. 2016; Tishkoff et al. 2009), before and during the slave trade and colonization era (Curtin 1961, 199o; Kiple 1993; Patterson 1993), and during the current post-independence era. This present era is marked by often-harmful structural adjustment reforms (Fetter 1993; Gilson and Mills 1995; Korte et al. 1992; Leighton 1995, 1996; World Bank 1994), the spread of new infections - primarily HIV/AIDS (Kagaayi and Serwadda 2016; Latham 1993; Worobey et al. 2008) - and the onset of the global aid industry (Easterly 2006; Moyo 2009; Ramalingam 2013). Using a literature review and the authors' perspectives gained through engagement in research and observation in the subcontinent, in this chapter we examine and reflect on current trends and forecasts of health in SSA for the twenty-first century with event horizons for the United Nations 2030 Sustainable Development Goals (SDG s) (UNDESA 2015) and the Africa Union (AU) 2063 Agenda (African Union Commission 2015).

\section{Current state and Causes of Population Health in} Sub-Saharan Africa

Comprising 47 World Health Organization (wHO)-Afro countries, SSA has a population of 1.07 billion people with a median age of 18 years (UNDESA 2019a). Of the 47 least developed countries in the world, 32 are in this region (UNDESA 2019b). While global poverty declined between 1990 and 2015, the number of people living below $\$ 1.9$ o per day in SSA has increased from 278 to 413 million, leaving most of the global poor concentrated in this region (World Bank 2018). Furthermore, while SSA's overall poverty rate stands at 41 percent 
(World Bank 2018), these countries have the most overlapping deprivations. Many countries experience severe multidimensional poverty (UNPD 2019: 69) owing to environmental factors and dysfunctional nation-state institutions historically dependent on an intractable postcolonial international aid regime (Collier and Gunning 1999; Easterly 2006; Wamai 2003). It is within this context that the state of population health in Africa must be understood.

Tables 1 and 2 summarize key health indicators for ssA with other world regions shown for comparison. A primary measure of survival and health system performance is life expectancy or longevity (van Raalte et al. 2018). Another key measure of population health used to estimate and compare the societal disease burden is the disability adjusted life year (DALY), which quantifies the loss of healthy, productive years of life due to disease (Murray and Lopez 2017; Salomon et al. 2012; World Bank 1993). Tables $1 \mathrm{~A}$ and $1 \mathrm{~B}$ show the size of the population, life expectancy, DALYs and healthy life expectancy (HALE) estimates for each World Health Organization (wHO) world region and in each country in SSA for 2016 and 2017.

TABLE 1A Estimates of total population, life expectancy of both sexes at birth in 2016, total disabilityadjusted life years in 2016, and healthy adjusted life expectancy in the six wHO regions

\begin{tabular}{|c|c|c|c|c|}
\hline $\begin{array}{l}\text { World Health } \\
\text { Organization } \\
\text { regions }\end{array}$ & $\begin{array}{l}\text { Population in } \\
2016(\text { ooos) }\end{array}$ & $\begin{array}{l}\text { Life } \\
\text { expectancy of } \\
\text { both sexes at } \\
\text { birth in } 2016^{\text {a }}\end{array}$ & $\begin{array}{l}\text { Total Disability } \\
\text { Adjusted Life } \\
\text { Years (DALYs) in } \\
2016 \text { (ooos) }^{\mathrm{b}}\end{array}$ & $\begin{array}{l}\text { Healthy } \\
\text { Adjusted } \\
\text { Life } \\
\text { Expectancy } \\
\text { (HALE) from } \\
\text { birth in } \\
2016^{\text {a }}\end{array}$ \\
\hline African region & 1020 & 61.2 & 598,615 & 53.8 \\
\hline European region & 916 & $77 \cdot 5$ & 300,416 & 68.4 \\
\hline $\begin{array}{l}\text { Eastern } \\
\text { Mediterranean } \\
\text { region }\end{array}$ & 664 & 69.1 & 251,108 & 60.51 \\
\hline $\begin{array}{l}\text { Region of the } \\
\text { Americas }\end{array}$ & 992 & 76.8 & 286,872 & 66.45 \\
\hline $\begin{array}{l}\text { South-East Asia } \\
\text { region }\end{array}$ & 1948 & 69.5 & $712,5^{22}$ & 60.59 \\
\hline $\begin{array}{l}\text { Western Pacific } \\
\text { region }\end{array}$ & 1890 & 76.9 & 510,444 & 68.04 \\
\hline
\end{tabular}


TABLE 1B Estimates of total population, life expectancy of both sexes at birth in 2016, total disabilityadjusted life years in 2016, and healthy adjusted life expectancy in 49 countries in sub-Saharan Africa region

$\begin{array}{lllll}\text { Sub-Saharan Africa } & \begin{array}{l}\text { Population } \\ \text { in } 2017\end{array} & \begin{array}{l}\text { Life } \\ \text { expectancy }\end{array} & \begin{array}{l}\text { Total Disability } \\ \text { Adjusted Life }\end{array} & \begin{array}{l}\text { Healthy } \\ \text { Adjusted Life }\end{array} \\ & (\text { ooos) } & \text { of both sexes } & \text { Years (DALY) in } & \text { Expectancy } \\ & & \text { at birth in } & 2016 \text { (ooos) } & \text { (HALE) from } \\ & & 2016 & & \text { birth in 2016 }\end{array}$

\begin{tabular}{|c|c|c|c|c|}
\hline Angola & 29817 & 62.6 & 16720.3 & 55.8 \\
\hline Benin & 11175 & 61.1 & 7063.1 & $53 \cdot 5$ \\
\hline Botswana & 2205 & 66.1 & 938.6 & $57 \cdot 5$ \\
\hline Burkina Faso & 19193 & 60.3 & $11597 \cdot 9$ & 52.9 \\
\hline Burundi & 10827 & 60.1 & $6727 \cdot 3$ & $5^{2.6}$ \\
\hline Cameroon & 24566 & 58.1 & 15809.6 & 51.1 \\
\hline Cape Verde & 537 & 73.2 & 138.6 & $64 \cdot 5$ \\
\hline Central African Rep & 4596 & 53 & 4171.1 & 44.9 \\
\hline Chad & 15017 & $54 \cdot 3$ & 13000 & 47.2 \\
\hline Comoros & 814 & $63 \cdot 9$ & $387 \cdot 4$ & $5^{6.6}$ \\
\hline Congo & 5111 & $64 \cdot 3$ & 2480.7 & $5^{6.7}$ \\
\hline Cote d'Ivoire & 24437 & 54.6 & 8297 & $48 \cdot 3$ \\
\hline Dem Rep of the Congo & 81399 & 60.5 & 54895 & 52.5 \\
\hline Djibouti & 944 & 63.8 & 451.4 & $5^{6.6}$ \\
\hline Equatorial Guinea & 1262 & 59.6 & 772.3 & 53.8 \\
\hline Eritrea & $5^{\circ 69}$ & 65 & 2110.9 & $57 \cdot 4$ \\
\hline Ethiopia & 106400 & $65 \cdot 5$ & 46507.4 & $57 \cdot 5$ \\
\hline Gabon & 2065 & 66.4 & 875.5 & 58.7 \\
\hline Gambia & 2214 & 61.9 & 1093 & $54 \cdot 4$ \\
\hline Ghana & 29121 & 63.4 & 13443.2 & $5^{6.4}$ \\
\hline Guinea & 12068 & 59.8 & 8039.1 & $5^{2.2}$ \\
\hline Guinea-Bissau & 1828 & 59.8 & 1143.4 & $5^{1 \cdot 7}$ \\
\hline Kenya & 50221 & 66.7 & $19507 \cdot 3$ & $5^{8.9}$ \\
\hline Lesotho & 2091 & $5^{2.9}$ & 1755.8 & 46.6 \\
\hline Liberia & $47 \mathrm{O} 2$ & 62.9 & 2513.8 & $54 \cdot 5$ \\
\hline Madagascar & 25571 & 66.1 & 10239.2 & $58 \cdot 3$ \\
\hline Malawi & 17670 & 64.2 & 8344.9 & 56.2 \\
\hline Mali & $185^{12}$ & $5^{8}$ & 13677.6 & $5^{\circ} \cdot 7$ \\
\hline Mauritania & 4283 & $63 \cdot 9$ & 2193.5 & 56.4 \\
\hline Mauritius & 1265 & 74.8 & 413.5 & 65.8 \\
\hline
\end{tabular}


TABLE 1B Estimates of total population, life expectancy of both sexes at birth in 2016, total disabilityadjusted life years in 2016, and healthy adjusted life expectancy in 49 countries in sub-Saharan Africa region (cont.)

$\begin{array}{lllll}\text { Sub-Saharan Africa } & \begin{array}{l}\text { Population } \\ \text { in } 2017\end{array} & \begin{array}{l}\text { Life } \\ \text { expectancy }\end{array} & \begin{array}{l}\text { Total Disability } \\ \text { Adjusted Life }\end{array} & \begin{array}{l}\text { Healthy } \\ \text { Adjusted Life }\end{array} \\ & (\text { ooos) } & \text { of both sexes } & \text { Years (DALY) in } & \text { Expectancy } \\ & & \text { at birth in } & 2016 \text { (ooos) } & \begin{array}{l}\text { (HALE) from } \\ \text { birth in 2016 }\end{array}\end{array}$

\begin{tabular}{lrrrr}
\hline Mozambique & 28649 & 60.1 & 17888.9 & 52.2 \\
Namibia & 2403 & $63 \cdot 7$ & 1129.1 & $55 \cdot 9$ \\
Niger & 21602 & 59.8 & 14971.7 & 52.5 \\
Nigeria & 190873 & $55 \cdot 2$ & 144976.6 & 48.9 \\
Rwanda & 11981 & 68 & 4407.2 & 59.9 \\
Sao Tome \& Principe & 207 & 68.7 & 70.4 & 60.7 \\
Senegal & 15419 & 66.8 & $6274 \cdot 5$ & 58.8 \\
Seychelles & 96 & $73 \cdot 3$ & 31.1 & $65 \cdot 7$ \\
Sierra Leone & 7488 & 53.1 & 6078.3 & 47.6 \\
Somalia & 14589 & $55 \cdot 4$ & 12176.6 & 50 \\
South Africa & 57000 & 63.6 & 27581.5 & $55 \cdot 7$ \\
South Sudan & 10911 & 58.6 & 8403.4 & 50.6 \\
Sudan & 40813 & 65.1 & 19381.5 & $55 \cdot 7$ \\
Swaziland (Eswatini) & 1125 & $57 \cdot 7$ & 830.6 & 50.2 \\
Togo & 54664 & 60.6 & 4331.8 & 53.9 \\
Uganda & 7698 & 62.5 & 4331.8 & 54.9 \\
U. Rep of Tanzania & 41162 & 63.9 & $27327 \cdot 7$ & 56.5 \\
Zambia & 16854 & 62.3 & 8883.4 & 54.3 \\
Zimbabwe & 14237 & 61.4 & $8437 \cdot 3$ & 54.4 \\
\hline
\end{tabular}

a World health statistics 2018: Monitoring health for the SDGs, sustainable development goals. 2018. Geneva: wHO.

b Global health estimates 2016: Disease burden by cause, age, sex, by country and by region, 2000-2016. 2018. Geneva: wно.

c World development indicators: Population, total. 2018. Washington: The World Bank. https://data. worldbank.org/indicator/sP.Рор.тотL.

These data show that Africa had the lowest life expectancy at 61.2 years in 2016, which rose slightly to 63.9 years in 2017 (GBD Collaborators 2018). A person born in Africa can expect to live an average of 16.3 fewer years than one born in the longest living population in the European region. At 7.4 years, the 
African region has the smallest HALE gap, meaning that the loss of health in this region is largely from premature mortality. By population size, sSA bears the greatest burden of disease with 22 per cent of global DALYs. A few variations by country are notable. For instance, the life expectancies in Mauritius (74.8), the Seychelles (73.3) and Cape Verde (73.2) are the highest in SsA, whereas Lesotho (52.9), Central African Republic (53) and Sierra Leone (53.1) have the lowest. These data show a startling reality: the average person in Mauritius can expect to live 21.9 years longer than the average person in Lesotho demonstrating health disparities between and within countries in SSA (Achoki et al. 2019; Leuenberger et al. 2019; Umuhoza and Ataguba 2018).

TABLE 2A Estimates on HIV prevalence, malaria deaths, TB cases per 100,000 population, NTD related deaths per 100,000 population, MMR, IMR and $\mathrm{U}_{5} \mathrm{MR}$ in the six WHO regions

\begin{tabular}{|c|c|c|c|c|c|c|c|}
\hline $\begin{array}{l}\text { WHO } \\
\text { regions }\end{array}$ & $\begin{array}{l}\text { HIV } \\
\text { (Prevalence } \\
\text { in 2019) })^{a}\end{array}$ & $\begin{array}{l}\text { Malaria } \\
\text { (deaths } \\
\text { in 2018) }{ }^{b}\end{array}$ & $\begin{array}{l}\text { ТВ (cases } \\
\text { per } 100,000 \\
\text { population } \\
\text { in } 2018)^{c}\end{array}$ & $\begin{array}{l}\text { NTDs (Death } \\
\text { per 10o,ooo } \\
\text { population in } \\
2017)^{d} \\
\end{array}$ & $\begin{array}{l}\text { MMR } \\
\text { (deaths } \\
\text { per } \\
\text { 10o,ooo } \\
\text { live } \\
\text { births in } \\
2017)^{\mathrm{e}}\end{array}$ & $\begin{array}{l}\text { IMR } \\
\text { (deaths } \\
\text { per } \\
\text { 1,ooo } \\
\text { live } \\
\text { births in } \\
2018)^{\mathrm{f}}\end{array}$ & $\begin{array}{l}\mathrm{U}_{5} \mathrm{MR} \\
\text { (deaths } \\
\text { per } \\
\text { 1000 } \\
\text { live } \\
\text { births } \\
\text { in } \\
2018)^{\mathrm{f}}\end{array}$ \\
\hline Africa & $25,700,000$ & 73276 & 231 & $2.841448 \circ 5^{2}$ & 542 & $5^{2}$ & 76 \\
\hline Europe & $2,500,000$ & o & 28 & $0.05838043^{6}$ & 13 & 7 & 9 \\
\hline $\begin{array}{l}\text { Eastern } \\
\text { Mediter- } \\
\text { ranean }\end{array}$ & 400,000 & 3320 & 115 & o.758439315 & 164 & 37 & 47 \\
\hline $\begin{array}{l}\text { Region } \\
\text { of the } \\
\text { Americas }\end{array}$ & $3,500,000$ & 337 & 29 & 1.169212984 & 57 & 12 & 14 \\
\hline $\begin{array}{l}\text { South- } \\
\text { East Asia }\end{array}$ & 3,800,0०0 & 164 & 220 & 2.30756315 & $15^{2}$ & 28 & 34 \\
\hline $\begin{array}{l}\text { Western } \\
\text { Pacific }\end{array}$ & 1,900,0०० & 243 & 96 & o.339356199 & 41 & 10 & 12 \\
\hline
\end{tabular}

Note: $\mathrm{NTD}=$ neglected tropical diseases; $\mathrm{MMR}$ = maternal mortality rate; $\mathrm{IMR}$ = infant mortality rate; $\mathrm{U}_{5} \mathrm{MR}=$ under five mortality rate. 
TABLE 2B Estimates on HIV prevalence, malaria deaths, Тв cases per 100, о0о population, NTD related deaths per 100,0oo population, MMR, IMR and $\mathrm{U}_{5} \mathrm{MR}$ in 49 countries in the sSA region

\begin{tabular}{|c|c|c|c|c|c|c|c|}
\hline $\begin{array}{l}\text { Countries of } \\
\text { SSA }\end{array}$ & $\begin{array}{l}\text { HIV (prev- } \\
\text { alence in } \\
2018)^{g}\end{array}$ & $\begin{array}{l}\text { Malaria } \\
\text { (deaths } \\
\text { in 2018) }\end{array}$ & $\begin{array}{l}\text { TB (cases } \\
\text { per } \\
\text { 10o,ooo } \\
\text { popula- } \\
\text { tion in } \\
2018)^{c}\end{array}$ & $\begin{array}{l}\text { NTDs (deaths } \\
\text { per 100,000 } \\
\text { population in } \\
2017)^{d}\end{array}$ & $\begin{array}{l}\text { MMR } \\
\text { (deaths } \\
\text { per } \\
\text { 100,00o } \\
\text { live } \\
\text { births in } \\
2017)^{\mathrm{e}}\end{array}$ & $\begin{array}{l}\text { IMR } \\
\text { (deaths } \\
\text { per 1,00o } \\
\text { live } \\
\text { births in } \\
2018)^{\mathrm{f}}\end{array}$ & $\begin{array}{l}\mathrm{U}_{5} \mathrm{MR} \\
\text { (deaths } \\
\text { per } \\
\text { 1000 } \\
\text { live } \\
\text { births - } \\
\text { 2018) }\end{array}$ \\
\hline Angola & 330,000 & 13425 & 355 & $5.230275 \circ 54$ & 241 & 51.59 & 77 \\
\hline Benin & 73000 & 7081 & $5^{6}$ & $3 \cdot 718408862$ & 397 & 60.54 & 93 \\
\hline Botswana & 370,000 & 2 & 275 & $0.3615^{28477}$ & 144 & 29.99 & 36 \\
\hline Burkina Faso & 96,o०o & 12725 & 48 & $4 \cdot 74227131$ & 320 & 49.01 & 76 \\
\hline Burundi & 82,000 & 5118 & 111 & 2.934575596 & 548 & 40.99 & $5^{8}$ \\
\hline Cameroon & 540,000 & 11192 & 186 & 3.069301502 & $5^{29}$ & $5^{0.56}$ & 76 \\
\hline Cape Verde & 2,400 & o & 46 & o.719316946 & $5^{8}$ & 16.67 & 19 \\
\hline \multicolumn{8}{|l|}{ Central } \\
\hline African Rep & 110,000 & 3654 & 540 & 5.830002483 & 829 & 84.46 & 116 \\
\hline Chad & 120,000 & 8693 & 142 & 6.612979802 & 1140 & 71.42 & 119 \\
\hline Comoros & 200 & 39 & 35 & $0.1986555^{22}$ & 273 & 51.25 & 67 \\
\hline Congo & 89,000 & 1961 & 375 & 2.09038986 & 378 & 36.19 & $5^{\circ}$ \\
\hline Cote d'Ivoire & 46o,ooo & 9297 & 142 & 3.838804416 & 617 & $59 \cdot 4$ & 81 \\
\hline \multicolumn{8}{|l|}{ Democratic } \\
\hline \multicolumn{8}{|l|}{ Republic of } \\
\hline Djibouti & $8,80 \circ$ & o & 260 & 0.844386026 & 248 & 49.81 & 59 \\
\hline \multicolumn{8}{|l|}{ Equatorial } \\
\hline Guinea & 62,000 & 659 & 201 & о. 677898612 & 301 & 62.62 & 85 \\
\hline Eritrea & 18 ,००० & 196 & 89 & 2.738347362 & 480 & 31.35 & 42 \\
\hline Ethiopia & 69o,ooo & 4757 & $15^{1}$ & 2.867944691 & 401 & $39 \cdot 15$ & 55 \\
\hline Gabon & 53,000 & $5^{28}$ & $5^{25}$ & $3 \cdot 371953473$ & $25^{2}$ & 32.7 & 45 \\
\hline Gambia & 26, ,०० & 688 & 174 & $2.9531983 \circ 7$ & 597 & 39.03 & $5^{8}$ \\
\hline Ghana & 330,000 & 11070 & 148 & 2.56643939 & 308 & 34.91 & 48 \\
\hline Guinea & 120,000 & 8203 & 176 & 7.94696o6o9 & 576 & 64.93 & 101 \\
\hline \multicolumn{8}{|l|}{ Guinea- } \\
\hline Bissau & 44,000 & 680 & 361 & $4.76400425^{8}$ & 667 & 54.02 & 81 \\
\hline Kenya & 1,6oo,o०o & 12416 & 292 & 1.079705478 & 510 & 30.62 & 41 \\
\hline Lesotho & 340,000 & - & 611 & o.268o95729 & 544 & 65.67 & 81 \\
\hline
\end{tabular}


TABLE 2B Estimates on HIV prevalence, malaria deaths, TB cases per 100,000 population, NTD related deaths per 100,00o population, MMR, IMR and U5MR in 49 countries in the SSA region (cont.)

\begin{tabular}{|c|c|c|c|c|c|c|c|}
\hline $\begin{array}{l}\text { Countries of } \\
\text { sSA }\end{array}$ & $\begin{array}{l}\text { HIV (prev- } \\
\text { alence in } \\
2018)^{g}\end{array}$ & $\begin{array}{l}\text { Malaria } \\
\text { (deaths } \\
\text { in 2018) }\end{array}$ & $\begin{array}{l}\text { TB (cases } \\
\text { per } \\
\text { 100,ooo } \\
\text { popula- } \\
\text { tion in } \\
2018)^{c}\end{array}$ & $\begin{array}{l}\text { NTDS (deaths } \\
\text { per 100,00o } \\
\text { population in } \\
2017)^{d}\end{array}$ & $\begin{array}{l}\text { MMR } \\
\text { (deaths } \\
\text { per } \\
\text { 100,00o } \\
\text { live } \\
\text { births in } \\
2017)^{\mathrm{e}}\end{array}$ & $\begin{array}{l}\text { IMR } \\
\text { (deaths } \\
\text { per 1,00o } \\
\text { live } \\
\text { births in } \\
2018)^{\mathrm{f}}\end{array}$ & $\begin{array}{l}\text { U5 }_{5} \text { MR } \\
\text { (deaths } \\
\text { per } \\
\text { 10oo } \\
\text { live } \\
\text { births - } \\
2018)^{\mathrm{f}}\end{array}$ \\
\hline
\end{tabular}

\begin{tabular}{|c|c|c|c|c|c|c|}
\hline Liberia & 39,000 & 2006 & 308 & $3 \cdot 593378283$ & 661 & 53.48 \\
\hline Madagascar & 39,000 & $535^{\circ}$ & 233 & 1.428913755 & 335 & 38.18 \\
\hline Malawi & 1,000,000 & 6478 & 181 & 3.284742834 & 634 & $35 \cdot 32$ \\
\hline Mali & 150,000 & 11848 & 53 & $5.013^{2} 65644$ & $5^{62}$ & 61.6 \\
\hline Mauritania & $5,6 \circ \circ$ & 1397 & 93 & $1.95 \circ 891615$ & 766 & 51.54 \\
\hline Mauritius & 13,000 & - & 13 & 0.143546612 & 61 & $13.5^{6}$ \\
\hline Mozambique & $2,200,000$ & 14426 & 551 & 1.45195146 & 289 & 54.02 \\
\hline Namibia & 200,000 & 132 & $5^{24}$ & 0.432922918 & 195 & 28.97 \\
\hline Niger & 36,000 & 17084 & 87 & 6.398866503 & $5 \circ 9$ & 47.98 \\
\hline Nigeria & 1,900,000 & 95844 & 219 & 4.005967667 & 917 & 75.67 \\
\hline Rwanda & 220,000 & 3244 & 59 & $0.953^{2216 \circ 3}$ & 248 & 27.02 \\
\hline
\end{tabular}

Sao Tome \&

Principe

Senegal

Seychelles

Sierra Leone

$\begin{array}{rrr}- & 0 & 12 \\ 42,000 & 4480 & 118 \\ & - & 18 \\ 70,000 & 6564 & 298 \\ 11,000 & - & 26 \\ 7,700,000 & 69 & 520 \\ 190,000 & 5356 & 146 \\ 59,000 & - & 7\end{array}$

3.446335137

130

24.43

31

Somalia

3.225229903

315

31.83

44

18

0.907969214

53

12.44

14

South Africa

3.893193646

1120

78.48

105

South Sudan

262

6.02875983

829

76.57

122

Sudan

0.082710233

119

28.49

34

16.61871735

1150

63.69

99

Swaziland

(Eswatini)

Togo

$$
\text { 210,000 }
$$

1.819378128

295

42.14

60

Uganda

110,000

$\begin{array}{rr}0 & 329 \\ 5132 & 36 \\ 13203 & 200\end{array}$

0.646712873

437

43.02

54

2.333569107

396

$47 \cdot 36$

70

United

2.706733709

375

33.81

46

Republic of

Tanzania 
TABLE 2B Estimates on HIV prevalence, malaria deaths, TB cases per 100,000 population, NTD related deaths per 100,000 population, MMR, IMR and U5MR in 49 countries in the SSA region (cont.)

\begin{tabular}{|c|c|c|c|c|c|c|c|}
\hline $\begin{array}{l}\text { Countries of } \\
\text { SSA }\end{array}$ & $\begin{array}{l}\text { HIV (prev- } \\
\text { alence in } \\
2018)^{g}\end{array}$ & $\begin{array}{l}\text { Malaria } \\
\text { (deaths } \\
\text { in 2018) }\end{array}$ & $\begin{array}{l}\text { ТВ (cases } \\
\text { per } \\
\text { 100,0oo } \\
\text { popula- } \\
\text { tion in } \\
2018)^{c}\end{array}$ & $\begin{array}{l}\text { NTDs (deaths } \\
\text { per 100,0oo } \\
\text { population in } \\
2017)^{d}\end{array}$ & $\begin{array}{l}\text { MMR } \\
\text { (deaths } \\
\text { per } \\
\text { 100,000 } \\
\text { live } \\
\text { births in } \\
2017)^{\mathrm{e}}\end{array}$ & $\begin{array}{l}\text { IMR } \\
\text { (deaths } \\
\text { per 1,00o } \\
\text { live } \\
\text { births in } \\
\text { 2018) }\end{array}$ & $\begin{array}{l}\mathrm{U}_{5} \mathrm{MR} \\
\text { (deaths } \\
\text { per } \\
\text { 1000 } \\
\text { live } \\
\text { births - } \\
\text { 2018) }\end{array}$ \\
\hline Zambia & $1,200,0 \circ 0$ & 7519 & 346 & 1.478407421 & 213 & 40.45 & $5^{8}$ \\
\hline Zimbabwe & $1,300,000$ & 1484 & 210 & 1.183912497 & $45^{8}$ & 33.9 & 46 \\
\hline
\end{tabular}

a Web Annex 1. Key data at a glance. In: Progress report on HIV, viral hepatitis and sexually transmitted infections 2019. Accountability for the global health sector strategies, 2016-2021. 2019, Geneva: World Health Organization.

b World malaria report 2019. 2019, Geneva: WHO.

c Global tuberculosis report 2019. 2019, Geneva:WHO.

d Global Burden of Disease Collaborative Network. Global burden of disease study. 2017, Seattle: Institute for Health Metrics and Evaluation.

e Global Health Observatory, maternal mortality ration (per 10oooo live births) dataset. 2017, Geneva: WHO.

f Levels and trends in child mortality: Estimates developed by the United Nations Inter-agency Group for Child Mortality Estimation (UN IGME)'. 2019, New York: UNICEF.

g HIV Country Profiles. $2018[3 / 31 / 2020]$.

Tables 2A and 2B illustrate the current situation for key diseases and health measures. ssA can be characterized by overlapping geographical distributions of three markers, namely high prevalence of HIV/AIDS, neglected tropical diseases (NTDS) and being overweight as a key risk for non-communicable diseases (NCD s) (Olesen and Parker 2012). Consequently, high disease burdens in western Africa are attributed to NTDs and NCDS. HIV and NCD dominate in southern Africa, while eastern and central Africa have all three markers. Increasing injuries related to urbanization and motorization, as well as continued regional conflicts, reveal a continent rife with a triple burden of disease (IHME et al. 2013). Underscoring these are pervasive mental health and substance abuse disorders that remain neglected (Charlson et al. 2014; Patel et 
al. 2018). SSA, however, remains the only region in the world where infectious diseases are the leading cause of death (GBD Collaborators 2018).

Comprising viral, parasitic and bacterial infections, $5^{\circ}$ per cent of global deaths and DALYs due to infectious diseases are in SSA (Boutayeb 2010a; Tambo et al. 2018). For most of these, SSA carries an even heavier burden: HIV/ AIDS (67.5 per cent of all 37.9 million people living with HIV, 67.5 per cent of new infections and 61 per cent of deaths in 2018 are in SSA) (UNAIDS 2019), and malaria (94 per cent and 95 per cent of global cases and deaths respectively in 2018) (WHO 2019a). For тв, the leading cause of infectious disease deaths globally, 24 per cent of cases in 2018 were in SSA as were 84 per cent of all твrelated deaths among people with HIV (WHO 2019b). Some NTD s like trypanosomiasis and schistosomiasis are overwhelmingly found in SSA (Boutayeb 2010b; Hotez and Kamath 2009). Furthermore, of nearly twenty infectious agents that contribute to NCD S (Olesen and Parker 2012) such as cervical cancer, the incidence and mortality in SSA is the highest globally (Bray et al. 2018).

Looking at population health, outcomes for women and children is of primary importance. As the WHO's 2005 seminal report on these groups articulated, "the healthy future of society depends on the health of the children of today and their mothers, who are guardians of that future" (WHO 2005: 1). Indicators of the health of women and children are, therefore, necessary to understand the performance of any health and political system. In 2015, SSA experienced 66.3 per cent (201,000) of 532,00o global maternal deaths (Alkema et al. 2016). These figures are an improvement since 1990, but as shown in Table $2 \mathrm{~A}$, at 542 maternal deaths per 100,00o live births, SSA is more than three times higher than the next highest wHO region. Despite improvements, infants and children under-five $\left(\mathrm{U}_{5}\right)$ years of age continue to die at higher rates in SSA than in any other world region. Of 5.3 million $U_{5}$ global deaths, 54 per cent in 2018 and $3_{1}^{1}$ per cent in 1990 were in SSA (UN IGME 2019). As shown in Table $2 \mathrm{~B}$, all six countries with $\mathrm{U}_{5}$ deaths above 100 per live birth are now in SSA, with Somalia (122) leading the pack followed by Nigeria (120).

The high burden of disease, poor population health outcomes and inequities are due to high levels of poverty, weak health systems, poor governance, historical colonialism and foreign aid policies. At the proximal level, high maternal deaths result from a failure to provide women with accessible quality health services. Many childhood deaths are attributable to low levels of immunization and childhood growth failure which is associated with nutrition and health access (for example, Alkema et al. 2016; Kinyoki et al. 202O; WHO 2017). Public perception of mental illness has historically stigmatized patients with mental health disorders and their families, who have often carried the burden of care (Gureje and Alem 200o; Patel et al. 2018). At the historical level, health inequities across and within countries such as those between Lesotho, 
Mauritius, Nigeria and South Africa reflect health and development policies rooted in colonial and apartheid systems with fragmented investments, weak institutions, impoverishment of large populations and the environmental, structural and organizational context of disease such as HIV/AIDS (Coovadia et al. 20o9; Hirschmann 1987; Ityavyar 1987; Latham 1993; Meredith 2011; Robinson 2011; Timberg and Halperin 2012).

However, a disenfranchising colonial experience is not an excuse for poor performance. Deliberately large welfare-state health investments in postcolonial Mauritius explain the positive outcomes in that country (Hirschmann 1987; Nundoochan et al. 2019; Seekings 2011). This is evidence that, with the right policies and governance, countries can achieve health improvements. Unfortunately, corruption and poor governance have exacerbated poverty for decades and exacted a toll on health development across SSA (Meredith 2011; Pring and Vrushi 2019; Wamai 2003), as funds allocated to improve the health infrastructure have been siphoned off for personal enrichment (Garcia 2019) through complex socio-structural systems (Vian 2008). For instance, models predict that corruption indirectly accounts for 140,000 child deaths annually (Hanf et al. 2011).

Given the well-established links between the burden of disease, longevity and economic productivity (Mwabu 1998; World Bank 1993; Zijdeman and de Silva 2014), a high disease burden clearly depresses Africa's economic and human development potential (Fenollar and Mediannikov 2018; Zeufack et al. 2020). Efforts to reform healthcare systems with ostensibly anti-corruption structural adjustments in the post-cold war era of the early 199os led to reduced foreign funding resulting in decreased national health budgets and worsening outcomes (Fetter 1993; Gilson and Mills 1995; Korte et al. 1992; Loewenson 1993; World Bank 1993). Since then, 25 years of developmentalism in the era of millennium development goals (MDG s) (1990-2015) vastly expanded the mainly foreign health investments, which led to improvements but fell short of meeting the set goals (Easterly 2009; English et al. 2015). These factors will continue to shape the subcontinent in the current era of SDG S (2016-2030) and beyond.

\section{The Next Decades: The Coming Epidemiological Transition}

Two decades into the twenty-first century, the state of population health in SSA is the baggage the subcontinent carries into the rest of this century. So, what is the outlook for the remaining eight decades, and beyond? Given the role of globalization in the dispersal of diseases, its expansion in Africa will continue to facilitate the bidirectional spread of emerging diseases. As Patterson (1993: 451) observes, Africa is an "epidemiological unit closely linked to the rest 
of the world". Severe acute respiratory syndrome-related coronavirus 2 (SARsCoV-2), which causes Covid-19, is the most poignant example in our time of the impact of globalization on the spread of diseases. As in the 1918/19 global influenza pandemic that killed 2 per cent of Africa's inhabitants (Patterson and Pyle 1983), COVID-19, which emerged from China, was introduced into Africa from outside with the first case reported in Egypt on 14 February 2020 (Africa CDC 2020). Therefore, the first lesson is that the future of health in Africa in this century cannot be understood in isolation from the rest of the world.

Numerous studies have projected scenarios driven by demographic and epidemiological transitions for health outcomes and disease burdens in SSA in the decades ahead (Mathers and Loncar 2006). In 2017, Agyepong et al. (2017) published a major Lancet Commission on the future of health in Africa. Authors reviewed the state and projections to 2030 of health data and provided recommendations for policy makers including addressing corruption and research innovation. Foreman et al. (2018) forecasted life expectancy, years of life lost, and all-cause and cause-specific mortality for 25 o causes of death in 195 countries and territories for 2016 to 2040, and found that the average sSA life expectancy will reach 71 years but will remain below all other regions. While childhood and maternal deaths decline, those due to road traffic accidents and NCD s are expected to increase (Agyepong et al. 2017; Foreman et al. 2018; Mathers and Loncar 2006). With economic growth, rapid urbanization, motorization and poor safety standards, road traffic accidents, already causing more deaths and injuries in SSA than anywhere else, will continue to increase (WHO 2018a). It will take 16o years before a pregnant woman in SSA has the same probability of giving birth to a living child as women in highincome countries (Lawn et al. 2016). Childhood growth failure is one of the biggest predictors of future population health. If current trends continue, the SDG target to end malnutrition by 2030 will not be met (Osgood-Zimmerman et al. 2018), and future generations will be affected by early childhood malnutrition, which contributes to cardiovascular disease and diabetes (Hult et al. 2010).

In the near term, specific disease targets - for example, reducing malaria deaths by 90 per cent by 2030 (wHO 2019a) and tuberculosis deaths by 95 per cent by 2035 (WHO 2019b) - are unlikely to be met. Likewise, while SSA has made significant progress towards meeting the global UNAIDS 95-95-95 goals - meaning that 95 per cent of those who are positive are aware of their HIV status, 95 per cent of these are on treatment and 95 per cent of these are virally suppressed - by 2030 (UNAIDS 2015a), achievements vary by country, age, gender and socio-demographic status (Green et al. 2020). Achieving these treatment targets will reduce the incidence of HIV, for example in Eswatini to 0.46 per 100 person-years by 2050 (Akullian et al. 2020). However, to set SSA on 
the path towards HIV elimination will require a combination of interventions targeted by profiles of population risk and geography (Eisinger et al. 2019; Khademi et al. 2015; McGillen et al. 2016; UNAIDS 2015b). Accelerated efforts are needed to meet the SDG targets of 70 women dying per 100,0oo live births and 25 deaths per 1000 live births (Alkema et al. 2016; UN IGME 2019).

Access to education and contraception for women is the panacea to slow down fertility rates (Local Burden of Disease Educational Attainment Collaborators 2020) and together with critical vaccines targeting the mother-child dyad (Kollmann et al. 2020; Lund et al. 2015; Munoz and Jamieson 2019; Velaphi et al. 2019; Vono et al. 2019), will make an impact on future maternal and childhood deaths. These targets and programmes are largely dependent on foreign funding. For instance, in 2015, $\$ 18$ billion was spent on HIV/AIDS in SSA of which more than 60 per cent was from donors such as the US President's Emergency Plan for AIDS Relief, the Global Fund for H IV/тв and Malaria and other non-governmental organizations (NG O s) (Micah et al. 2019; Wamai 2014). Such high dependency means that many African lives are literally in the hands of global politics in the USA and Europe. A sharp example is where, following the election of President Trump, proposed reductions in the US President's Malaria Initiative, which provides one-fifth of global malaria financing, could have resulted in 290,00o malaria deaths between 2017 and 2020 (Winskill et al. 2017). Furthermore, with huge gaps in funding required to meet the set targets and decreasing donor financing it is essential that governments and donors improve efficient resource utilization and accountability (Agyepong et al. 2017; Kavanagh et al. 2019).

\section{5 \\ Infectious Diseases Dominate the First Half of the Twenty-First Century}

In 2006, Rweyemamu, from Tanzania, and his two Ugandan colleagues published a report for the UK Office of Science and Innovation's Foresight programme called Infectious diseases: preparing for the future Africa (Rweyemamu et al. 2006). Using a disease risk-driver framework developed in consultation with key African experts and forecasting to the present decade, the report depicts a dire and complex picture of the impact of and future threats posed by infectious diseases, most notably the combined effects on societies of the 'one health' - humans, animals and the natural environment - dimension. Given that 12 of the 15 most contagious animal diseases are found in Africa (Rweyemamu et al. 2006: 5), and that 22 of the 25 most vulnerable countries to infectious diseases are in Africa, the other three being Afghanistan, Haiti and 
Yemen (Moore et al. 2016), human behaviour, including demographic changes, migration and consumption patterns, will present the highest disease risk this century (Fenollar and Mediannikov 2018; Rweyemamu et al. 2006).

Diseases associated with poverty, such as those caused by poor household air, childhood nutritional deficiencies, and unsafe water and sanitation, along with limited access to healthcare services, which contributes to maternal and child deaths, will remain the leading causes of years of life lost in 2040 (Foreman et al. 2018). If current trends continue, nearly nine out of ten people in extreme poverty will be in SSA in 2030 (UNDP 2019), further accentuating the many infectious diseases of poverty, especially the NTDs (WHO 2012). More than any other disease HIV/AIDS casts a persistent shadow on SSA. Labelled a 'time bomb' (Rweyemamu et al. 2006: 4), HIV/AIDS prevents SSA countries with high prevalence from achieving significant mortality declines (National Research Council 2006; Norheim et al. 2015), so it will continue to affect health and development. For example, even with higher social development indices than other ssA countries, South Africa, Namibia and Botswana have lower longevity outcomes because of the high rates of HIV/AIDS (GBD Collaborators 2018). Further, HIV will drive the burden of disease by comprising the greatest cause of DALY s in 2030 under the 2002 baseline (Mathers and Loncar 2006). As treatment expands and infections persist one model predicts that 70 million people could be living with HIV by 2050 in SSA (Institute of Medicine 2011).

The value of predicting patterns of infectious disease spread in metapopulations such as SSA in the twenty-first century has been made abundantly clear by the ongoing outbreak of the new CoviD-19 pandemic (Achoki et al. 2020; Balcan and Vespignani 2011; Davis et al. 2020). The sustained threat posed by the pandemic underscores a need for strong public health systems, both for COVID-19 and emerging diseases yet unknown. In the short term, early modelling predicted that COVID-19 cases and deaths in SSA would reach 16 million and 34,000 respectively by the end of June 2020 (Achoki et al. 2020). Another model projects 122.8 million cases and 300,00o deaths in the best-case scenario by the end of 2020 and 1.4 per cent contraction in economic growth (Economic Commission for Africa 2020). While no models are accurate and should be adjusted as new data become available, the long-term effects of this pandemic on vaccine-preventable infectious diseases due to the discontinuation of mass immunization campaigns will likely be immense if observations from the 2014/15 West African Ebola epidemic hold true (Parpia et al. 2016; Roberts 2020). COVID-19 notwithstanding, SSA faced 96 disease outbreaks in 36 of 47 countries in 2018 (Mboussou et al. 2019) and currently has 48 highlevel single or multi-country infectious disease events requiring an international response (wHO 202O). This calls for critical investments in infectious 
disease surveillance and coordination of health emergencies across the countries (Nkengasong 2019) and preparedness for Disease X (Simpson et al. 2020).

\section{$6 \quad$ Non-Communicable Diseases Will Become the Leading Causes of Death After 2050}

In 2017 , NCD s accounted for 73 per cent of 55.9 million global deaths (GBD Collaborators 2018). An epidemiological transition has been occurring in SSA, especially since the 1990s (IHME et al. 2013; National Research Council 2006, 2012). The contribution of NCD s to all SSA DALY s rose by 67 per cent between 1990 and 2017 (Gouda et al. 2019). We predict that at some point this century the overall disease burden from NCD s will overtake infectious diseases, although that will be after the year 2040 (Foreman et al. 2018). For some countries such as Kenya and South Africa, this transition is modelled to happen in the current decade (Osetinsky et al. 2019a), while hospitalization data in countries like Uganda show growing rates of NCDs and declining infectious diseases (Kalyesubula et al. 2019). Major NCD s facing SSA include cancers, hypertension, diabetes and heart disease (Farmer et al. 2010; NCD-RisC 2016; Stewart et al. 2017; van de Vijver et al. 2013).

By 2030 one study estimates that cancer cases and deaths in SSA will rise from 681,000 and 512,000 in 2008 to 1.27 million and 0.97 million respectively (Sylla and Wild 2012). A projected 9o per cent of 443,000 annual cervical cancer deaths will be in SSA by 2030 (Mboumba Bouassa et al. 2017). The hypertensive population is projected to increase to 126 million by 2025 from 75 million in 2008 (Twagirumukiza et al. 2011). Projections for 2035 and 2045 predict diabetes in SSA will increase 156 per cent from 2017 , the greatest increase globally (Cho et al. 2018; Guariguata et al. 2014). Hypertension will increase to 46 per cent from 40 per cent in KwaZulu-Natal and to 35 per cent from 29 per cent in rural western Kenya between 2018 and 2028 (Osetinsky et al. 2019a). Even as most people with diabetes and hypertension on the continent still remain undiagnosed, the spread of the NCD s will vary across countries (Gouda et al. 2019; Yaya et al. 2018).

In addition, mental health and substance use disorders in SSA are expected to increase as a share of the total burden of disease within the coming decades, rising from 19 million years lost to disability to 45 million by mid-century (Charlson et al. 2014; Gouda et al. 2019). Significant gaps between current and needed mental health workers could widen without adequate investment in training and awareness programmes for mental health disorders given that the per capita mental health workforce in Africa stands at 0.9 per 100,000 and 
only 27 per cent of countries have allocated resources to meet national mental health policies, both far below other world regions (wHO 2018b). Therefore, strengthening mental health policies (Gureje and Alem 200o; Patel et al. 2018), task shifting (Galárraga et al. 2017) and leveraging community health workers (Chibanda 2017; Collins et al. 2016) could be a means of establishing affordable health interventions that bridge a treatment gap estimated to be over 9o per cent for some mental and substance use disorders (Agyepong et al. 2017).

At the cross-section of infectious diseases and NCD s is the growing burden and neglect of surgically treatable diseases. As highlighted in the 2015 Lancet Commission on Global Surgery, expanding access to safe surgical care is an essential piece of a national health package (Meara et al. 2015). An estimated ${ }^{28}{ }^{2}{ }^{2}$ per cent of the global burden of disease can be attributed to surgically treatable conditions (Meara et al. 2015), a category that encompasses NCDs, infectious diseases, and injuries. Despite being a cost-effective mechanism to improve livelihoods, upwards of 95 per cent of people living in SsA do not have reliable, affordable surgical care (Alkire et al. 2015). Thus, SSA governments must allocate funds for surgery, anaesthesia and obstetric care and capacity building into national healthcare budgets to fill gaps and meet SDG targets. While regionwide efforts remain forthcoming, progress has been made on this front. For example, Ethiopia's Saving Lives through Safe Surgery (SaLTS) initiative, has achieved significant strides in improving surgical access and training a robust surgical workforce (Burssa et al. 2017; Federal Ministry of Health of Ethiopia 2017).

As SSA's demographic transition progresses in the coming decades, so must health policies and health systems. The share of people over the age of 60 will have doubled by 2030 and will continue to grow at an annual rate of about 4 per cent (compared with 1 per cent for developed countries) over the period of fifty years (National Research Council 2006). This epidemiological transition is being driven by multiple factors, including urbanization, lifestyle changes, ageing and fertility declines (Saghir and Santoro 2018; Sliwa 2016; UNDESA 2019a, 2019b) all of which can be managed through appropriate policies and learning. In response to the looming NCD threat, especially later in the twentyfirst century, SSA countries must strengthen surveillance and health systems (Gouda et al. 2019; Mudie et al. 2019; Nkengasong 2019; Wamai et al. 2018) and adopt a model in which interventions are integrated across disease groups and health system levels, which cuts costs and saves lives (Kasaie et al. 2020; Nugent et al. 2018; Osetinsky et al. 2019b). As one example, programmes to control HIV such as male circumcision are modelled to reduce the incidence of cervical cancer by 28 per cent and mortality by 26 per cent by the year 2070 in Tanzania (Hall et al. 2020). 
The future of health in SSA is precarious yet promising. This could be the century for Africa. Without question, because of the global impact of COVID-19, the pandemic presents the biggest immediate and direct threat to SSA in 2020, demanding a coordinated global, regional and national response (African Union 2O2O; WHO 202O; Zeufack et al. 202O). The pandemic poses further indirect threats in synergy with outbreaks of other raging infectious diseases (Mboussou et al. 2019; WHO 2020). Beyond COVID-19, however, growing economies will allow countries to increase financing for health and expand opportunities. Having increased by the largest global margins in SSA between 2005 and 2015, life expectancy at birth (UNDP 2019:40) in the subregion could catch up with the rest of the world by the end of the century. Unfortunately, the subregion will remain vulnerable to the impact of climate change - a crisis to which it contributes little - and while epidemiological and demographic transitions present new threats, global pandemics will afflict ever larger populations.

Furthermore, the region remains tied to global frameworks, such as SDGs, over which it has little control due to its ensuing reliance on global financing. Even as these SDG s have been dubbed "senseless, dreamy, garbled" by a development economist (Easterly 2015) and as "fairy tales dressed in the bureaucratese of intergovernmental narcissism with the robes of multilateral paralysis, and poisoned by the acid of nation-state failure" by the editor of the Lancet (Horton 2014), the entire development community seems to believe that these hold an unquestionable promise for a better world. However, given that the health of Africans has suffered in the hands of the structural adjustments of the past, and been unfairly set to fail to meet the MDG s (Easterly 2009), there is indeed cause for pessimism if the new development agenda is framed within a paradigm of foreign aid steeped in colonial history and dysfunctional postcolonial corruption (Easterly 2006; Moyo 2009; Ramalingam 2013). A persistent global funding gap for pandemics strongly affecting the ssA already reaches \$23-35 billion (Kavanagh et al. 2019). Foreign donors perpetuate colonial relationships by imposing political, cultural, and religious morals and demands on recipient countries (Garrett 2007). Furthermore, well-funded NGO s and foreign governments siphon the local health workforce, leading to Africa's great brain drain, and hamstringing health infrastructure across the continent (Darkwa 2018; Garrett 2007). As such, business as usual foreign donor largesse is not going to save the subcontinent.

Mitigating these futures is only going to be possible through deliberate political investments and African-grown and led models that adjust rather 
than bend to the international health regime. At the same time, health improvements in Africa will not be achieved without robust health systems (Agyepong et al. 2017; Gros 2015; Moeti 2017; Prince and Marsland 2014), and these show critical vulnerabilities in the context of pandemics (Gilbert et al. 2020). Furthermore, SSA will increasingly need to refashion its health systems to meet changing patterns of disease, including expanding the availability of healthcare workers and ensuring effective and high quality universal health coverage (UHC) (Kruk et al. 2018; Moeti 2017; Nkengasong 2019). Recruiting an army of millions of community health workers (CHWs) is a low-hanging fruit, given the existing experience of the many countries across which they provide numerous primary healthcare services and are highly cost-effective (McCord et al. 2013; Singh and Sachs 2013; UNAIDS 2017). Due to their frontline role in contact-tracing in past pandemic diseases (Miller et al. 2018; Siekmans et al. 2017), CHWs might just be the panacea for UHC and in combating the current COVID-19 and future disease outbreaks.

The third edition of the Disease Control Priorities in Developing Countries (DCP3) seminal reports provided a framework for population health covering service delivery packages, policies, and platforms for essential and expanded services to 2030 (Jamison et al. 2017). The policies fall into five broad areas information and communication, taxes and subsidies, regulation, mass screening and treatment of diseases, and engineering (for example, towards a safer road traffic infrastructure). In the context of SSA, essential services include reproductive, maternal, newborn and child health, cancer, surgery, and mental health. To match these demands, countries that rely largely on high outof-pocket and donor financing will need to bear an increasing burden in the decades approaching 2040 and 2050 (Global Burden of Disease Health Financing Collaborator Network 2018; Chang et al. 2019). However, historically, at just 2 per cent, the average health spending per person in SSA, even by the betteroff countries (National Research Council 2012), is pitifully inadequate with heavy foreign reliance. Despite increases between 1995 and 2015, wide variations occur in government per capita spending - for example, $\$ 651$ in Namibia versus $\$ 4$ in the Central African Republic (Micah et al. 2019). In 2040, per capita spending would still be the lowest in the world at $\$ 175$ versus $\$ 7508$ in high income countries (Global Burden of Disease Health Financing Collaborator Network 2018).

For far too long, heavy reliance on foreign funding creates power imbalances in health policy ownership with African governments often hamstrung (Gautier and Ridde 2017; Kiendrébéogo and Meessen 2019). Although donor funding has improved lives and plugs some budgetary shortfalls, African governments can move towards autonomy by meeting the 2001 Abuja Declaration of investing 15 per cent of government spending on health (WHO 2011). But this is not enough. 
Micah et al. (2019) show that besides increased spending, governments must also combat corruption. With better domestic health governance, use of law in strengthening health systems, protecting population health, and human rights, increased domestic funding would allow countries to rely less on donor funding, achieve UHC and the SDG s and build an 'African Century' (Agyepong et al. 2017; Gostin et al. 2019). Overall, interventions to improve health in this century must be targeted towards population needs and infrastructural demands and be illuminated by the equity policies set out initially in the first Africa Health Strategy of 2007 and other landmark commitments including 'The Africa We Want' Agenda 2063, the SDG s and the Africa Health Strategy 2015-2030 (Africa Union Department of Social Affairs 2016). While these strategies offer a path to the future for Africa, the wider path for the 'African Century' will be shaped by the resilience and optimism of its populations.

\section{References}

Achoki, T., M. K. Miller-Petrie, S. D. Glenn, N. Kalra, A. Lesego, G. K. Gathecha, U. Alam, et al. 2019. "Health disparities across the counties of Kenya and implications for policy makers, 1990-2016: A systematic analysis for the global burden of disease study 2016." Lancet Global Health, 7, 1: e81-e95. Dor: 10.1016/s2214$109 x(18) 30472-8$.

Achoki, T., U. Alam, L. Were, T.e Gebremedhin, F. Senkubuge, A. Lesego, S. Liu, R. Wamai and Y. Kinfu. 2020. "COVID-19 pandemic in the African continent: Forecasts of cumulative cases, new infections, and mortality." medRxiv, 28 April. Dor: 10.1101/2020.04.09.20059154.

Africa CDC (Africa Centres for Disease Control and Prevention). 2020. "COVID-19." https://africacdc.org/covid-19/. Last modified 28 April 2020 [20 April 2020].

African Union. 2020. Africa joint continental strategy for COVID-19 outbreak. Addis Ababa: African Union. https://africacdc.org/download/africa-joint-continentalstrategy-for-covid-19-outbreak/.

African Union Commission. 2015. Agenda 2063:The Africa we want. Addis Ababa:African Union. https://au.int/sites/default/files/documents/36204-doc-agenda2o63_popular_version_en.pdf.

Africa Union Department of Social Affairs. 2016. Africa health strategy 2016-2030. Addis Ababa: African Union. https://au.int/sites/default/files/documents/30357-docfinal_ahs_strategy_formatted.pdf [21 April 2020].

Agyepong, I. A., N. Sewankambo, A. Binagwaho, A. M. Coll-Seck, T. Corrah, et al. 2017. "The path to longer and healthier lives for all Africans by 2030: The Lancet Commission on the future of health in sub-Saharan Africa." The Lancet, 39o, 10114: 2803-59. DoI: 10.1016/So140-6736(17)315o9-X. 
Akullian, A., M. Morrison, G. P. Garnett, Z. Mnisi, N. Lukhele, D. Bridenbecker and A. Bershteyn. 2020. "The effect of 90-90-90 on HIV-1 incidence and mortality in eSwatini: A mathematical modelling study." The Lancet HIV, 7, 5: E348-E358.

Alkema, L., D. Chou, D. Hogan, S. Zhang, A.-B. Moller, A. Gemmill, et al. 2016. "Global, regional, and national levels and trends in maternal mortality between 1990 and 2015, with scenario-based projections to 2030: A systematic analysis by the UN Maternal Mortality Estimation Inter-Agency Group." The Lancet, 387, 10017: 462474. D OI: 10.1016/So140-6736(15)oo838-7.

Alkire, B. C., N. P. Raykar, M. G. Shrime, T. G. Weiser, S. W. Bickler, J. A. Rose, et al. 2015. "Global access to surgical care: A modelling study." The Lancet Global Health, 3, 6: e316-323. DoI: 10.1016/S2214-109X(15)70115-4.

Balcan, D. and A. Vespignani. 2011. "Phase transitions in contagion processes mediated by recurrent mobility patterns." Nature Physics, 7: 581-586. DoI: 10.1038/nphys1944.

Baten, J. and M. Blum. 2014. "Human height since 1820." In How was life? Global wellbeing since 1820, edited by J. L. van Zanden, et al., 117-137. Paris: OECD Publishing.

Boutayeb, A. 2010a. "The burden of communicable and non-communicable diseases in developing countries," In Handbook of disease burdens and quality of life measures, edited by V. R. Preedy and R. R. Watson, 531-546. New York: Springer.

Boutayeb, A. 2010b. "The burden of neglected diseases in developing countries." In Handbook of disease burdens and quality of life measures, edited by V. R. Preedy and R. R. Watson, 517-529. New York: Springer.

Braun, L. and E. Hammonds. 2008. "Race, populations, and genomics: Africa as laboratory." Social Science and Medicine, 67, 10: 1580-1588. DoI: 10.1016/j.socscimed.2008.07.018.

Bray, F., J. Ferlay, I. Soerjomataram, R. L. Siegel, L. A. Torre and A. Jemal. 2018. "Global cancer statistics 2018: GLOBOCAN estimates of incidence and mortality worldwide for 36 cancers in 185 countries." CA: A Cancer Journal for Clinicians, 68, 6: 394424. DOI: $10.3322 /$ caac.21492.

Brynildsrud, O. B., C. S. Pepperell, P. Suffys, L. Grandjean, J. Monteserin, N. Debech, J. Bohlin, et al. 2018. "Global expansion of Mycobacterium tuberculosis lineage 4 shaped by colonial migration and local adaptation." Science Advances, 4, 10:article eaat5869. DoI: 10.1126/sciadv.aat5869.

Burssa, D., A. Teshome, K. Iverson, O. Ahearn, T. Ashengo, D. Barash, E. Barringer, et al. 2017. "Safe surgery for all: Early lessons from implementing a national governmentdriven surgical plan in Ethiopia." World Journal of Surgery, 41, 12: 3038-3045. W: 10.1007/soo268-017-4271-5.

Chang, A. Y., K. Cowling, A. E. Micah, A. Chapin, C. S. Chen, G. Ikilezi, N. Sadat, et al. 2019. "Past, present, and future of global health financing: A review of development assistance, government, out-of-pocket, and other private spending on health for 195 countries, 1995-205o." The Lancet, 393, 10187: 2233-226o. 
Charlson, F. J., S. Diminic, C. Lund, L. Degenhardt and H. A. Whiteford. 2014. "Mental and substance use disorders in sub-Saharan Africa: Predictions of epidemiological changes and mental health workforce requirements for the next 40 years." PLoS ONE, 9, 10. DOI: 10.1371/journal.pone.o110208.

Chibanda, D. 2017. "Reducing the treatment gap for mental, neurological and substance use disorders in Africa: Lessons from the Friendship Bench in Zimbabwe." Epidemiology and Psychiatric Sciences, 26, 4: 342-347. DOI: 10.1017/S2045796016001128.

Cho, N. H., J. E. Shaw, S. Karuranga, Y. Huang, J. D. da Rocha Fernandes, A. W. Ohlrogge and B. Malanda. 2018. "IDF diabetes atlas: Global estimates of diabetes prevalence for 2017 and projections for 2045." Diabetes Research and Clinical Practice, 138: 271281. DOI: 10.1016/j.diabres.2018.02.023.

Collier, P. and J. W. Gunning. 1999. “Explaining African economic performance." Journal of Economic Literature, 37, 1: 64-111.

Collins A., M. A Alzain, S. Andrea, R. Alexander and W. Wang. 2016. "Integration of community health workers into health systems in developing countries: Opportunities and challenges." Family Medicine and Community Health, 4, 1: 37-45. DOI: 10.15212/FMCH.2O16.0102.

Coovadia, H., R. Jewkes, P. Barron, D. Sanders and D. McIntyre. 20o9. "The health and health system of South Africa: Historical roots of current public health challenges." The Lancet, 37, 4: 817-834.

Curtin, P. D. 1961. “'The white man's grave:' Image and reality, 1780-1850." Journal of British Studies, 1, 1: 94-110. DOI: 10.1086/385437.

Curtin, P. D. 199o. “The end of the 'white man's grave'? Nineteenth-century mortality in West Africa." The Journal of Interdisciplinary History, 21, 1: 63-88. DoI: $10.2307 / 204918$.

Davis, J. T., N. Perra, Q. Zhang, Y. Moreno and A. Vespignani. 2020. "Phase transitions in information spreading on structured populations." Nature Physics, 16:590-596. DoI: 10.1038/s41567-020-0810-3.

Dawka, S K. 2018. "From brain-drain to brain-gain: The African-diaspora community and development in Africa." Africology: The Journal of Pan African Studies, 12, 5:14-35.

Easterly, W. 2006. The white man's burden: Why the West's efforts to aid the rest have done so much ill and so little good. New York: Penguin Press.

Easterly, W. 2009. "How the millennium development goals are unfair to Africa." World Development, 37, 1: 26-35.

Easterly, W. 2015. "The SDGs should stand for senseless, dreamy, garbled." Foreign Policy, 28 September. http://foreignpolicy.com/2015/og/28/the-sdgs-are-utopian-andworthless-mdgs-development-rise-of-the-rest/.

Economic Commission for Africa. 2020. COVID-19 in Africa: Protecting lives and economies. Addis Ababa: Economic Commission for Africa. https://www.uneca.org/sites/ default/files/PublicationFiles/eca_covid_report_en_revı6april_5web.pdf. 
Eisinger, R. W., C. W. Dieffenbach, A. S. Fauci. 2019. "HIV viral load and transmissibility of HIV infection: Undetectable equals untransmittable." JAMA, 321, 5: 451-452. DOI: 10.1001/jama.2018.21167.

English, M., E. English and A. English. 2015. "Millennium development goals progress: A perspective from sub-Saharan Africa." Archives of Disease in Childhood, 100, S1: S57-58. DOI: 10.1136/archdischild-2013-305747.

Farmer, P., J. Frenk, F. M. Knaul, L. N. Shulman, G. Alleyne, L. Armstrong, R. Atun, et al. 2010. "Expansion of cancer care and control in countries of low and middle income: A call to action." The Lancet, 376, 9747: 1186-1193. DOI: 10.1016/ So140-6736(10)61152-X.

Federal Ministry of Health of Ethiopia. 2017. Saving lives through safe surgery (SaLTS): Strategic plan 2016-2020. Addis Ababa: FмOH. https://static1.squarespace.com/ static/56b8ed53b6aa6o9o3fe8e7f5/t/5e578777144ced2c2aab85ab/158279461998o/2_ SaLTS+Strategic+Plan.pdf.

Fenollar, F. and O. Mediannikov. 2018. "Emerging infectious diseases in Africa in the 21st century." New Microbes and New Infections, 26, S1: S1O-18. DoI: 10.1016/j. nmni.2018.09.004.

Fetter, B. 1993. "Health care in twentieth century Africa: Statistics, theories, and policies." Africa Today, 40, 3: 9-23.

Foreman, K. J., N. Marquez, A. Dolgert, K. Fukutaki, N. Fullman, M. McGaughey, et al. 2018. "Forecasting life expectancy, years of life lost, and all-cause and cause-specific mortality for 250 causes of death: Reference and alternative scenarios for 2016-40 for 195 countries and territories." The Lancet, 392, 10159: 2052-209o. DoI: 10.1016/ So140-6736(18)31694-5.

Galárraga, O., B. Gao, B. N. Gakinya, D. A. Klein, R. G. Wamai, J. E. Sidle and R. K. Papas. 2017. "Task-shifting alcohol interventions for HIV+ persons in Kenya: A cost-benefit analysis." BMC Health Services Research, 17, 239. DOI: 10.1186/s12913-017-2169-4.

Garcia, P J. 2019. "Corruption in global health: The open secret." The Lancet, 394, 10214: 2119-2124. DOI: 10.1016/So140-6736(19)32527-9.

Garrett, L. 2007. "The challenge of global health." Foreign Affairs, 86, 1: 14-38.

Gautier, L. and V. Ridde. 2017. "Health financing policies in sub-Saharan Africa: Government ownership or donors' influence? A scoping review of policymaking processes." Global Health Research and Policy, 2, 23. DOI: 10.1186/s41256-017-0043-X.

GBD Collaborators (GBD 2017 Mortality Collaborators). 2018. "Global, regional, and national age-sex-specific mortality and life expectancy, 1950-2017." The Lancet, 392, 10159: 1684-1735. DOI: 10.1016/So140-6736(18)31891-9; and "Global, regional, and national age-sex-specific mortality for 282 causes of death in 195 countries and territories, 1980-2017: A systematic analysis for the Global Burden of Disease Study 2017." The Lancet, 392, 10159: 1736-1788. DoI: 10.1016/So140-6736(18)32203-7. 
Gilbert, M., G. Pullano, F. Pinotti, E. Valdano, C. Poletto, P.-Y. Boëlle, E. D’Ortenzio, Y. Yazdanpanah, S. P. Eholie, M. Altmann, et al. 2020. "Preparedness and vulnerability of African countries against importations of COVID-19: A modelling study." The Lancet, 395, 10227: 871-877.

Gilson, L. and A. Mills. 1995. "Health sector reforms in sub-Saharan Africa: Lessons of the last 10 years." Health Policy, 32, 1/3: 215-243. Dor: 10.1016/o1688510(95)oo737-D.

Global Burden of Disease Health Financing Collaborator Network. 2018. "Trends in future health financing and coverage: Future health spending and universal health coverage in 188 countries, 2016-40." The Lancet, 391, 10132: 1783-1798. DoI: 10.1016/ So140-6736(18)30697-4.

Gostin, L. O., J. T. Monahan, J. Kaldor, M. DeBartolo, E. A. Friedman, K. Gottschalk, S. C. Kim, A. Alwan, A. Binagwaho, et al. 2019. "The legal determinants of health: Harnessing the power of law for global health and sustainable development." The Lancet, 393, 10183: 1857-1910. DoI: 10.1016/So140-6736(19)30233-8.

Gouda, H. N., F. Charlson, K. Sorsdahl, S. Ahmadzada, A. J. Ferrari, H. Erskine, et al. 2019. "Burden of non-communicable diseases in sub-Saharan Africa, 1990-2017: Results from the Global Burden of Disease Study 2017." The Lancet Global Health, 7 , 10: e1375-e1387. DOI: 10.1016/S2214-109X(19)30374-2.

Green, D., D. M. Tordoff, B. Kharono, A. Akullian, A. Bershteyn, M. Morrison, G. Garnett, A. Duerr and P. K. Drain. 2O2O. "Evidence of sociodemographic heterogeneity across the HIV treatment cascade and progress towards 9o-9o-9o in sub-Saharan Africaa systematic review and meta-analysis." Journal of the International AID S Society, 23 , 3. DOI: $10.1002 /$ jia2.25470.

Gros, J.-G. 2015. Healthcare policy in Africa: Institutions and politics from colonialism to the present. Lanham: Rowman \& Littlefield.

Guariguata, L., D. R. Whiting, I. Hambleton, J. Beagley, U. Linnenkamp and J. E. Shaw. 2014. "Global estimates of diabetes prevalence for 2013 and projections for 2035." Diabetes Research and Clinical Practice, 103, 2: 137-149. DOI: 10.1016/ j.diabres.2013.11.002.

Gureje, O. and A. Alem. 200o. "Mental health policy development in Africa." Bulletin of the World Health Organization, 78, 4: 475-482.

Hall, M. T., M. A. Smith, K. T. Simms, R. V. Barnabas, K. Canfell and J. M. Murray. 2020. "The past, present and future impact of HIV prevention and control on HPV and cervical disease in Tanzania: A modelling study." PLoS ONE, 15, 5: eO231388. DOI: 10.1371/journal.pone.0231388.

Hanf, M., A. Van-Melle, F. Fraisse, A. Roger, B. Carme and M. Nacher. 2011. "Corruption kills: Estimating the global impact of corruption on children deaths." PLoS One, 6, 11: e2699o. DoI: 10.1371/journal.pone.oo2699o. 
Horton, R. 2014. "Offline: Why the Sustainable Development Goals will fail." The Lancet, 383, 9936: 2196.

Hirschmann, D. 1987. "Early post-colonial bureaucracy as history: The case of the Lesotho Central Planning and Development Office, 1965-1975." The International Journal of African Historical Studies, 20, 3: 455-470.

Hotez, P. J. and A. Kamath. 20o9. "Neglected tropical diseases in sub-Saharan Africa: Review of their prevalence, distribution, and disease burden." PLoS Neglected Tropical Diseases, 3, 8: e412. DoI: 10.1371/journal.pntd.oooo412.

Hult, M., P. Tornhammar, P. Ueda, C. Chima, A.-K. Edstedt Bonamy, B. Ozumba, and M. Norman. 2010. "Hypertension, diabetes and overweight: Looming legacies of the Biafran famine." PLoS ONE , 5, 10: e13582. DOI: 10.1371/journal.pone.oo13582.

IHME (Institute for Health Metrics and Evaluation), Human Development Network, World Bank. 2013. The global burden of disease. Generating evidence, guiding policy: Sub-Saharan Africa regional edition. Seattle: IH ME. http://documents1.worldbank .org/curated/en/831161468191672519/pdf/8o852oPUBoENGLoBoxo37982oBooPUB LICo.pdf.

Institute of Medicine. 2011. Preparing for the future of HIV/AIDS in Africa: A shared responsibility. Washington, DC: National Academies Press. DOI: 10.17226/12991.

Ityavyar, D. A. 1987. "Background to the development of health services in Nigeria." Social Science \& Medicine, 24, 6: 487-499. Dor: 10.1016/o277-9536(87)90338-8.

Jackson, P. 2020. "This will be Africa's century." Financial Times, 30 January. https:// www.ft.com/content/65e 74935-3217-4528-9eab-ococ4ed17of3.

Jamison, D.T., R. G. Feacham, M. W. Makgoba, E. R. Bos, F. K. Baingana, K. J. Hofman and K. O. Rogo. 2006. Disease and mortality in sub-Saharan Africa. Washington: World Bank Publications.

Jamison, D. T., H. Gelband, S. Horton, P. Jha, C. N. Mock and R. Nugent. 2017. Disease control priorities, third edition (volume 9): Improving health and reducing poverty. Washington: World Bank Publications.

Kagaayi, J. and D. Serwadda. 2016. "The history of the HIV/AIDS epidemic in Africa." Current HIV/AIDS Reports, 13, 4: 187-193. DOI: 10.1007/s11904-016-o318-8.

Kalyesubula, R., I. Mutyaba, T. Rabin, I. Andia-Biraro, P. Alupo, I. Kimuli, S. Nabirye, et al. 2019. "Trends of admissions and case fatality rates among medical in-patients at a tertiary hospital in Uganda a four-year retrospective study." PLOS ONE, 14, 5: eo216o6o. DOI: 10.1371/journal.pone.o216o6o.

Kasaie, P., B. Weir, M. Schnure, C. Dun, J. Pennington, Y. Teng, R. Wamai, K. Mutai, D. Dowdy and C. Beyrer. 202O. "Integrated screening and treatment services for HIV, hypertension and diabetes in Kenya: Assessing the epidemiological impact and cost-effectiveness from a national and regional perspective". Journal of the International AIDs Society, 23: e25499.

Kavanagh, M. M., H. Thirumurthy, R. Katz, K. L. Ebi, C. Beyrer, J. Headley, C. B. Holmes, C. Collins and L. O. Gostin. 2019. "Ending pandemics: US foreign policy to miti- 
gate today's major killers, tomorrow's outbreaks, and the health impacts of climate change." Journal of International Affairs, 73, 1.

Khademi, A., S. Anand and D. Potts. 2015. "Measuring the potential impact of combination HIV prevention in sub-Saharan Africa." Medicine, 94, 37: e1453. DoI: 10.1097/ MD.oooooooooooo1453.

Kiendrébéogo, J. A. and B. Meessen. 2019. "Ownership of health financing policies in low-income countries: A journey with more than one pathway." BMJ Global Health, 4: eoo1762. DoI: 10.1136/bmjgh-2019-0o1762.

Kinyoki, D. K., A. E. Osgood-Zimmerman, B. V. Pickering, L. E. Schaeffer, L. B. Marczak, et al. 2020. "Mapping child growth failure across low- and middle-income countries." Nature, 577: 231-234. DOI: 10.1038/s41586-019-1878-8.

Kiple, K. F. 1993. "Diseases of sub-Saharan Africa to 186o." In The Cambridge world history of human disease, edited by K. F. Kiple, 293-298. Cambridge: Cambridge University Press.

Kollmann, T. R., A. Marchant, S. S. Way. 2020. "Vaccination strategies to enhance immunity in neonates." Science, 368, 6491: 612-615.

Korte, R., H. Richter, F. Merkle and H. Görgen. 1992. "Financing health services in subSaharan Africa: Options for decision makers during adjustment." Social Science \& Medicine, 34, 1: 1-9. DoI: 10.1016/o277-9536(92)9oo6o-4.

Kruk, M. E., A. D. Gage, C. Arsenault, K. Jordan, H. H. Leslie, S. Roder-Dewan, O. Adeyi, et al. 2018. "High-quality health systems in the sustainable development goals era: Time for a revolution." The Lancet Global Health, 6, 11: e1196-1252. DoI: 10.1016/ S2214-109X(18)3०386-3.

Latham, M. C. 1993. "AIDS in Africa: A perspective on the epidemic." Africa Today, 40, 3: 39-53.

Lawn, J.E., H. Blencowe, P. Waiswa, A. Amouzou, C. Mathers, D. Hogan, V. Flenady, et al. 2016. "Stillbirths: Rates, risk factors, and acceleration towards 2030 ." The Lancet, 387 , 10018: 587-6o3. DOI: 10.1016/So140-6736(15)oo837-5.

Leighton, C. 1995. "Overview: Health financing reforms in Africa." Health Policy Plan, 10, 3: 213-222. DOI: 10.1093/heapol/10.3.213.

Leighton, C. 1996. "Strategies for achieving health financing reform in Africa." World Development, 24, 9: 1511-1525. DOI: 10.1016/o305-75०X(96)ooo58-7.

Leuenberger, A., A. Farnham, S. Azevedo, H. Cossa, D. Dietler, B. Nimako, P. B. Adongo, et al. 2019. "Health impact assessment and health equity in sub-Saharan Africa: A scoping review." Environmental Impact Assessment Review, 79:106288. DO I:10.1016/j. eiar.2019.106288.

Local Burden of Disease Educational Attainment Collaborators. 2020. "Mapping disparities in education across low- and middle-income countries." Nature, 577, 7789: 235-238. DOI: 10.1038/s41586-019-1872-1.

Loewenson, R. 1993. "Structural adjustment and health policy in Africa." International Journal of Health Services, 23, 4: 717-730. 
López, S., L. Van Dorp and G. Hellenthal. 2016. "Human dispersal out of Africa: A lasting debate." Evolutionary Bioinformatics, 11S2. DoI: 10.4137/EBO.S33489.

Lund, N., A. Andersen, A. S. K. Hansen, F. S. Jepsen, A. Barbosa, S. Biering-Sørensen, A. Rodrigues, H. Ravn, P. Aaby and C. S. Benn. 2015. "The effect of oral polio vaccine at birth on infant mortality: A randomized trial." Clinical Infectious Diseases, 61, 10: 1504-1511. DOI: 10.1093/cid/civ617.

Lyons, M. 1992. The colonial disease: A social history of sleeping sickness in northern Zaire, 1900-1940. New York: Cambridge University Press.

McCord, G. C., A. Liu and P. Singh. 2013. "Deployment of community health workers across rural sub-Saharan Africa: Financial considerations and operational assumptions." Bulletin of the World Health Organization, 91, 4: 244-253. DOI: 10.2471/ BLT.12.10966o.

McGillen, J. B., S.-J. Anderson, M. R. Dybul and T. B. Hallett. 2016. "Optimum resource allocation to reduce HIV incidence across sub-Saharan Africa: A mathematical modelling study." Lancet HIV, 3, 9: e441-448. DoI: 10.1016/S2352-3018(16)30051-o.

Mathers, C. D. and D. Loncar. 2006. "Projections of global mortality and burden of disease from 2002 to 2030." PLoS Medicine, 3, 11: e442. DOI: 10.1371/journal. pmed.oo30442.

Mboussou, F., P. Ndumbi, R. Ngom, Z. Kamassali, O. Ogundiran, J. Van Beek, G. Williams, C. Okot, E. L. Hamblion, and B. Impouma. 2019. "Infectious disease outbreaks in the African region: Overview of events reported to the World Health Organization in 2018." Epidemiology \& Infection, 147: e299. DoI: 10.1017/So950268819001912.

Mboumba Bouassa, R. S., T. Prazuck, T. Lethu, J. F. Meye and L. Bélec. 2017. "Cervical cancer in sub-Saharan Africa: An emerging and preventable disease associated with oncogenic human papillomavirus." Médecine et Santé Tropicales, 27, 1: 16-22. DOI: 10.1684/mst.2017.0648.

Meara, J. G., A. J. M. Leather, L. Hagander, B. C. Alkire, N. Alonso, et al. 2015. "Global Surgery 2030: Evidence and solutions for achieving health, welfare, and economic development." The Lancet, 386, 9993: 569-624. Dor: 10.1016/So140-6736(15)6o16o-X.

Meredith, M. 2011. The fate of Africa: A history of fifty years of independence. New York: Public Affairs.

Micah, A. E., C. S. Chen, B. S. Zlavog, G. Hashimi, A. Chapin and J. L. Dieleman. 2019. "Trends and drivers of government health spending in sub-Saharan Africa, 19952015." BMJ Global Health, 4: eoo1159.

Miller, N. P., P. Milsom, G. Johnson, J. Bedford, A. S. Kapeu, A. O. Diallo, K. Hassen, et al. 2018. "Community health workers during the Ebola outbreak in Guinea, Liberia, and Sierra Leone." Journal of Global Health, 8, 2: 0206o1. DoI: 10.7189/jogh-o8-0206o1.

Moeti, M. 2017. "Longer and healthier lives for all Africans by 2030: Perspectives and action of WHO AFRO." The Lancet, 390, 10114: 2747-2749. DOI: 10.1016/So14O6736(17)32128-1. 
Moore, M., B. Gelfeld, A. Okunogbe and C. Paul. 2016. Identifying future disease hot spots: Infectious disease vulnerability index. Santa Monica, CA: RAND. DOI: 10.7249/ RR16o5.

Moyo, D. 20og. Dead aid: Why aid is not working and how there is a better way for Africa. London: Allen Lane.

Mudie, K., M. M. J. Tan, L. Kendall, J. Addo, I. dos-Santos-Silva, J. Quint, et al. 2019. “Noncommunicable diseases in sub-Saharan Africa: A scoping review of large cohort studies." Journal of Global Health, 9, 2: O2O409. DOI: 10.7189/jogh.09.020409.

Munoz, F. M. and D. J. Jamieson. 2019. "Maternal immunization." Obstetric Gynecology, 133, 4: 739-753.

Murray, C. J. L. and A. D. Lopez. 2017. "Measuring global health: Motivation and evolution of the global burden of disease study." The Lancet, 390, 10100: 1460-1464. DoI: 10.1016/So140-6736(17)32367-X.

Mwabu, G. 1998. "Health development in Africa." Economic Research Papers, No. 38. https://core.ac.uk/download/pdf/6430884.pdf.

National Research Council. 2006. Aging in sub-Saharan Africa: Recommendations for furthering research. National Research Council (US) Committee on Population, edited by B. Cohen and J. Menken. Washington, DC: The National Academies Press.

National Research Council. 2012. The continuing epidemiological transition in subSaharan Africa: A workshop summary. Washington DC: National Academies Press.

NCD-RisC (NCD Risk Factor Collaboration) 2016. "A century of trends in adult human height." eLife, 5. DOI: 10.7554/eLife.13410.

Nkengasong, J. N. 2019. "How Africa can quell the next disease outbreaks." Nature, 567: 147. DOI: $10.1038 / \mathrm{d} 41586-019-00789-4$.

Norheim, O. F., P. Jha, K. Admasu, T. Godal, R. J. Hum, M. E. Kruk, O. Gomez-Dantes, et al. 2015. "Avoiding 40\% of the premature deaths in each country, 2010-30: Review of national mortality trends to help quantify the un sustainable development goal for health." The Lancet, 385, 9964: 239-252. DoI: 10.1016/so140-6736(14)61591-9.

Nugent, R., R. V. Barnabas, I. Golovaty, B. Osetinsky, A. Roberts, C. Bisson, L. Courtney, P. Patel, G. Yonga and D. Watkins. 2018. "Costs and cost-effectiveness of HIV/noncommunicable disease integration in Africa: From theory to practice." AIDS, 32, S1: S83-92. DoI: 10.1097/QAD.oooooooooooo1884.

Nundoochan, A., Y. Thorabally, S. Monohur and J. Hsu. 2019. "Impact of out of pocket payments on financial risk protection indicators in a setting with no user fees: The case of Mauritius." International Journal for Equity in Health, 18, 63. DOI: 10.1186/ s12939-019-0959-5.

Olesen, O. F. and M. I. Parker. 2012. "Health research in Africa: Getting priorities right." Tropical Medical and International Health, 17, 9: 1048-1052. DOI: 10.1111/j.13653156.2012.03027.x. 
Osetinsky, B., J. A. C. Hontelez, M. N. Lurie, S. T. McGarvey, G. S. Bloomfield, S. D. Pastakia, R. Wamai, et al. 2019a. "Epidemiological and Health Systems Implications of Evolving Hiv and Hypertension in South Africa and Kenya." Health Affairs (Millwood), 38, 7: 1173-1181. DoI: 10.1377/hlthaff.2018.05287.

Osetinsky, B., B. L. Genberg, G. S. Bloomfield, J. Hogan, S. Pastakia, E. Sang, A. Ngressa, A. Mwangi, M. N. Lurie, S. T. McGarvey, et al. 2019b. "Hypertension control and retention in care among HIV-infected patients: The effects of co-located HIV and chronic noncommunicable disease care." Journal of Acquired Immune Deficiency Syndromes, 82, 4: 399-406. DOI: 10.1097/QAI.oooooooooooo2154.

Osgood-Zimmerman, A., A. Millear, R. Stubbs, et al. 2018. "Mapping child growth failure in Africa between 2000 and 2015." Nature, 555, 41-47. DOI: 10.1038/nature2576o.

Parpia, A. S., M. L. Ndeffo-Mbah, N. S. Wenzel and A. P. Galvani. 2016. "Effects of response to 2014-2015 Ebola outbreak on deaths from malaria, HIV/AIDS, and tuberculosis, West Africa." Emerging Infectious Disease Journal, 22, 3: 433-441. DoI: 10.3201/eid2203.150977.

Patel, V., S. Saxena, C. Lund, G. Thornicroft, F. Baingana, P. Bolton, D. Chisholm, et al. 2018. "The Lancet Commission on global mental health and sustainable development." The Lancet, 392, 10157:1553-1598. DoI: 10.1016/So140-6736(18)31612-X.

Patterson, D. K. 1993. "Disease ecologies of sub-Saharan Africa." In The Cambridge world history of disease, edited by K. Kiple, 447-452. Cambridge: Cambridge University Press.

Paterson, K. D. and G. F. Pyle. 1983. "The diffusion of influenza in sub-Saharan Africa during the 1918-1919 pandemic." Social Science and Medicine, 17, 17: 1299-1307. DoI: 10.1016/o277-9536(83)90022-9.

Prince, R. J. and R. Marsland. 2014. Making and unmaking public health in Africa: Ethnographic and historical perspectives. Athens: Ohio University Press.

Pring, C. and J. Vrushi. 2019. Global corruption barometer Africa 2019: Citizens'views and experiences of corruption. Berlin: Transparency International.

Ramalingam, B. 2013. Aid on the edge of chaos: Rethinking international cooperation in a complex world. Oxford: Oxford University Press.

Roberts, L. 2020. "Pandemic brings mass vaccinations to a halt." Science, 368, 6487: 116-117. DOI: 10.1126/science.368.6487.116.

Robinson, R. S. 2011. "From population to HIV: The organizational and structural determinants of HIV outcomes in sub-Saharan Africa." Journal of the International AIDS Society, 14, S2: S6. DoI: 10.1186/1758-2652-14-S2-S6.

Rweyemamu, M., W. Otim-Nape and D. Serwadda. 2006. Foresight. Infectious diseases: Preparing for the future Africa. London: Office of Science and Innovation. https:// assets.publishing.service.gov.uk/government/uploads/system/uploads/attachment_data/file/29481o/o6-1768-infectious-diseases-africa.pdf. 
Saghir, J. and J. Santoro. 2018. Urbanization in sub-Saharan Africa: Meeting challenges by bridging stakeholders. Washington DC: Center for Strategic and International Studies.

Salomon, J. A., T. Vos, D. R. Hogan, M. Gagnon, M. Naghavi, A. Mokdad, N. Begum, et al. 2012. "Common values in assessing health outcomes from disease and injury: Disability weights measurement study for the Global Burden of Disease Study 2010." The Lancet, 380, 9859: 2129-2143. DoI: 10.1016/So140-6736(12)6168o-8.

Seekings, J. 2011. "British colonial policy, local politics, and the origins of the Mauritian welfare state, 1936-50." Journal of African History, 52, 2: 157-177.

Siekmans, K., S. Sohani, T. Boima, F. Koffa, L. Basil and S. Laaziz. 2017. "Communitybased health care is an essential component of a resilient health system: Evidence from Ebola outbreak in Liberia." BMC Public Health, 17, 1: 84. DOI: 10.1186/s12889 -016-4012-y.

Simpson, S., M. C. Kaufmann, V. Glozman and A. Chakrabarti. 2020. "Disease X: Accelerating the development of medical countermeasures for the next pandemic." The Lancet Infectious Diseases, 20, 5:E108-115, DoI: 10.1016/S1473-3099(20)30123-7.

Singh, P. and J. D. Sachs. 2013. "1 million community health workers in sub-Saharan Africa by 2015." The Lancet, 382, 9889: 363-365. DoI: 10.1016/So140-6736(12)62002-9.

Sliwa, K. 2016. "The heart of Africa: Succeeding against the odds." Lancet, 388, 10063: e28-36.

Stewart, S., K. Sliwa, A. Mocumbi, A. Damasceno and M. Ntsekhe. 2017. The heart of Africa: Clinical profile of an evolving burden of heart disease in Africa. Hoboken: John Wiley \& Sons.

Sylla, B. S. and C. P. Wild. 2012. "A million Africans a year dying from cancer by 2030: What can cancer research and control offer to the continent?" InternationalJournal of Cancer, 130, 2: 245-250. DOI: 10.1002/ijc.26333.

Tambo, E., S. Xia, F. Xin-Yu and Z. Xiao-Nong. 2018. "Digital surveillance and communication strategies to infectious diseases of poverty control and elimination in Africa." Journal of Infectious Disease Epidemiology, 4, 3. DOI: 10.23937/2474-3658/1510056.

The Economist. 2000. "The hopeless continent." The Economist, 13 May. https://www. economist.com/weeklyedition/2000-05-13.

Timberg, C. and D. Halperin. 2012 Tinderbox: How the West sparked the AIDS epidemic and how the world can finally overcome it. New York: Penguin Books.

Tishkoff, S. A. and S. M. Williams. 2002. "Genetic analysis of African populations: Human evolution and complex disease." Nature Review: Genetics, 3, 8: 611-621. DoI: $10.1038 / \mathrm{nrg} 865$.

Tishkoff, S. A., F. A. Reed, F. R. Friedlaender, C. Ehret, A. Ranciaro, A. Froment, et al. 2009. "The genetic structure and history of Africans and African Americans." Science, 324, 5930: 1035-1044. DoI: 10.1126/science.1172257. 
Twagirumukiza, M., D. De Bacquer, J. G. Kips, G. de Backer, R. V. Stichele, and L. M. Van Bortel. 2011. "Current and projected prevalence of arterial hypertension in subSaharan Africa by sex, age and habitat: An Estimate from population studies." Journal of Hypertension, 29, 7:1243-1252. D OI: 10.1097/HJH.obo13e328346995d.

Umuhoza, S. M. and J. E. Ataguba. 2018. "Inequalities in health and health risk factors in the southern African Development Community: Evidence from World Health Surveys." International Journal for Equity in Health, 17, 52. Dor: 10.1186/s12939-018-0762-8. UNAIDS (Joint United Nations Programme on HIV/AIDS). 2015a. Fast-track: Ending the AIDS epidemic by 2030. Geneva: UNAIDS. http://www.unaids.org/sites/default/ files/media_asset/JC2686_WAD2014report_en.pdf.

UNAIDS (Joint United Nations Programme on HIV/AIDS) 2015b. Fast-tracking combination prevention: Towards reducing new HIV infections to fewer than 500 ooo by 2020. Geneva: UNAIDS. http://www.unaids.org/sites/default/files/media_asset/20151019_ JC2766_Fast-tracking_combination_prevention.pdf [22 April 2020].

UNAIDS (Joint United Nations Programme on HIV/AIDS). 2017. 2 million African community health workers: Harnessing the demographic dividend, ending AIDS and ensuring sustainable health for all in Africa. Geneva: UNAIDs. https://www.unaids. org/en/resources/documents/2017/African2mCHW [15 May 2020].

UNAIDS (Joint United Nations Programme on HIV/AIDS). 2019. UNAIDS data 2019. Geneva: Joint United Nations Programme on HIV/AIDs. https://www.unaids.org/ sites/default/files/media_asset/2019-UNAIDS-data_en.pdf.

UndesA (United Nations Department of Economic and Social Affairs). 2015. "Sustainable development goals." https://sustainabledevelopment.un.org/sdgs [2 March 2O2O].

UN DESA. 2019a. World population prospects: Highlights (ST/ESA/SER.A/423). New York: UN DESA, Population Division. https://population.un.org/wpp/Publications/Files/ WPP2019_Highlights.pdf.

UN DESA. 2019b. World population prospects 2019, volume I: Comprehensive tables. New York: UN DESA, Population Division. https://population.un.org/wpp/Publications/ Files/WPP2019_Volume-I_Comprehensive-Tables.pdf.

UNDP (United Nations Development Programme). 2019. Human development report 2019. Beyond income, beyond averages, beyond today: Inequalities in human development in the 21st century. New York: UNDP. http://hdr.undp.org/sites/default/ files/hdr2o19.pdf.

UN IGME (United Nations Inter-agency Group for Child Mortality Estimation). 2019. Levels and trends in child mortality. New York: UNICEF. https:/www.unicef.org/ reports/levels-and-trends-child-mortality-report-2019.

van de Vijver, S., H. Akinyi, S. Oti, A. Olajide, C. Agyemang, I. Aboderin and C. Kyobutungi. 2013. "Status report on hypertension in Africa - consultative review for the 6th session of the African Union Conference of Ministers of Health on NCD's." The Pan African Medical Journal, 16: 38. DoI: 10.116o4/pamj.2013.16.38.3100. 
van Raalte, A. A., I. Sasson and P. Martikainen. 2018. "The case for monitoring life-span inequality." Science, 362, 6418: 1002-1004. DoI: 10.1126/science.aau5811.

Velaphi, S. C., M. Westercamp, M. Moleleki, T. Pondo, Z. Dangor, N. Wolter, A. von Gottberg, et al. 2019. "Surveillance for incidence and etiology of early-onset neonatal sepsis in Soweto, South Africa." PLoS ONE, 14, 2019: eo214O77. DOI: 10.1371/journal. pone.0214077.

Vian, T. 2008. "Review of corruption in the health sector: Theory, methods and interventions." Health Policy and Planning, 23, 2: 83-94. DoI: 10.1093/heapol/czmo48.

Vono, M., C. S. Eberhardt, F. Auderset, B. Mastelic-Gavillet, S. Lemeille, D. Christensen, P. Andersen, P.-H. Lambert and C.-A. Siegrist. 2019. "Maternal antibodies inhibit neonatal and infant responses to vaccination by shaping the early-life b cell repertoire within germinal centers." Cell Reports, 28, 7: 1773-1784. DoI: 10.1016/j.celrep.2019.07.047.

Wamai, R. G. 2003. "The state and development in the South: A review of contemporary debates." In Development: Concepts, policies and practices. Essays in memory of Michael Cowen, edited by T. Kontinen, and M. Seppanen, 81-118. Helsinki: Finnish Society for Development Studies.

Wamai, R. G. 2014. "Civil society organizations and the response to the HIV/AIDS crisis in Africa." In The handbook of civil society in Africa, edited by E. Obadare, $361-398$. New York: Springer International.

Wamai, R. G., A. P. Kengne and N. Levitt. 2018. "Non-communicable diseases surveillance: Overview of magnitude and determinants in Kenya from STEPwise approach survey of 2015." BMC Public Health, 18, S3: article 1224. D OI: 10.1186/s12889-018-6o51-z. Weill, F.X., D. Domman, E. Njamkepo, C. Tarr, J. Rauzier, N. Fawal, K. H. Keddy, et al. 2017. "Genomic history of the seventh pandemic of cholera in Africa." Science, 358, 6364: 785-789. DoI: 10.1126/science.aad5901.

Wells, S. 2002. The journey of man: A genetic odyssey. Princeton: Princeton University Press.

wHo (World Health Organization). 2005. The world health report 2005 - make every mother and child count. Geneva: wHO. https://www.who.int/whr/2005/whr2005_ en.pdf.

wHo (World Health Organization). 2011. The Abuja Declaration: Ten years on. Geneva: wHo. https://www.who.int/healthsystems/publications/abuja_report_aug_2011.pdf. wHO (World Health Organization). 2012. Global report for research on infectious diseases of poverty. Geneva: wHо on behalf of the Special Programme for Research and Training in Tropical Diseases. http://apps.who.int/iris/bitstr eam/10665/4485o/1/9789241564489_eng.pdf.

WH (World Health Organization). 2017. Global health observatory, maternal mortality ration (per 100 ooo live births) dataset. Geneva: wH 0.

wHo (World Health Organization). 2018a. Global status report on road safety 2018. Geneva: wHo. 
WHO (World Health Organization). 2018b. Mental health atlas 2017. Geneva: WHO.

https://www.who.int/mental_health/evidence/atlas/mental_health_atlas_2017/en/. wH (World Health Organization). 2019a. World malaria report 2019. Geneva: WHO.

wHo (World Health Organization). 2019b. Global tuberculosis report 2019. Geneva: WHO.

wH (World Health Organization). 2020. Weekly epidemiological record, 8 May. Geneva: wHO. https://apps.who.int/iris/bitstream/handle/10665/332018/WER9519-eng-fre.pdf.

Winskill, P., H. C. Slater, J. T. Griffin, A. C. Ghani and P. G. T. Walker. 2017. "The US President's Malaria Initiative, Plasmodium falciparum transmission and mortality: A modelling study." PLoS Med, 14, 11: e1002448. DoI:10.1371/journal.pmed.1002448.

World Bank. 1993. World development report 1993: Investing in health. New York: Oxford University Press.

World Bank. 1994. Better health in Africa: Experience and lessons learned (English). Washington DC: World Bank. http://documents.worldbank.org/curated/ en/816231468oo3293729/Better-health-in-Africa-experience-and-lessons-learned.

World Bank. 2007. Africa development indicators 2007. Washington, DC: World Bank. http://siteresources.worldbank.org/INTSTATINAFR/Resources/adi2007_final.pdf.

World Bank. 2008. Global monitoring report 2008. Washington DC: World Bank. https:// www.imf.org/external/Pubs/FT/GMR/20o8/eng/gmr.pdf.

World Bank. 2011. Africa development indicators 2011. Washington DC: World Bank. http://siteresources.worldbank.org/INTAFRICA/Resources/ADI_2011.pdf.

World Bank. 2018. Poverty and shared prosperity 2018: Piecing together the poverty puzzle. Washington DC: World Bank. https://openknowledge.worldbank.org/bitstream/handle/1o986/30418/9781464813306.pdf.

Worobey, M., M. Gemmel, D. E. Teuwen, T. Haselkorn, K. Kunstman, M. Bunce, J. J. Muyembe, et al. 2008. "Direct evidence of extensive diversity of HIV-1 in Kinshasa by 196o." Nature, 455, 7213: 661-664. Dor: 10.1038/natureo739o.

Yaya, S., M. Ekholuenetale and G. Bishwajit. 2018. "Differentials in prevalence and correlates of metabolic risk factors of non-communicable diseases among women in sub-Saharan Africa: Evidence from 33 countries." вмс Public Health, 18, 1: article 1168. Dor: $10.1186 / \mathrm{s} 12889-018-6085^{-2}$.

Zeufack, A. G., C. Calderon, G. Kambou, C. Z. Djiofack, M. Kubota, V. Korman and C. Catalina Cantu. 2020. "Africa's pulse: An analysis of issues shaping Africa's economic future." Volume 21, World Bank Group. DoI: 10.1596/978-1-4648-1568-3.

Zijdeman, R. L. and F. R. de Silva. 2014. "Life expectancy since 1820". In How was life? Global well-being since 1820, edited by J. van Zanden, et al., 101-116. Paris: OECD Publishing. 